\title{
Transatlantica
}

Revue d'études américaines. American Studies Journal

\section{The Crumbling Two-Story Architecture of Richard Powers' Fictions}

\section{Thomas B. Byers}

\section{Q OpenEdition}

1 Journals

\section{Édition électronique}

URL : https://journals.openedition.org/transatlantica/4510

DOI : 10.4000/transatlantica.4510

ISSN : 1765-2766

Éditeur

Association française d'Etudes Américaines (AFEA)

Référence électronique

Thomas B. Byers, «The Crumbling Two-Story Architecture of Richard Powers' Fictions », Transatlantica [En ligne], 2 | 2009, mis en ligne le 07 février 2010, consulté le 31 janvier 2023. URL : http:// journals.openedition.org/transatlantica/4510; DOI : https://doi.org/10.4000/transatlantica.4510

Ce document a été généré automatiquement le 31 janvier 2023.

\section{(c) (i) (9)}

Creative Commons - Attribution - Pas d'Utilisation Commerciale - Pas de Modification 4.0 International - CC BY-NC-ND 4.0

https://creativecommons.org/licenses/by-nc-nd/4.0/ 


\title{
The Crumbling Two-Story Architecture of Richard Powers' Fictions
}

\author{
Thomas B. Byers
}

\author{
"Books may be a substantial world, but the world \\ of substance, the blue, species-mad world at \\ year's end outstrips every card catalog I can \\ make for it." \\ -Richard Powers, The Gold Bug Variations (317)
}

1 Most of the novels of Richard Powers share a common structural pattern. They have two distinct story lines, which generally take place in different times and spaces, and which sometimes-though by no means always-focus on quite different sets of characters ${ }^{1}$. Thus The Gold Bug Variations alternates between the story of Stuart Ressler's young professional life and affair with Jeanette Koss on the one hand, and the story of Ressler, Franklin Todd, and Jan O'Deigh (including the affair of the latter two) about thirty years later. In Galatea 2.2, a narrator named Richard Powers intersperses the history of his several years' relationship and cohabitation with a woman identified as C. with the story of a year spent in collaboration with scientist Philip Lentz in an attempt to train a neural net to interpret literature. In Gain, the poignant case history of Laura Bodey, a young single mother dying of ovarian cancer, alternates with the 170-year history of the Clare Soap and Chemical Company. Plowing the Dark tells the very different stories of Adie Klarpol, an artist working on a wondrous virtual reality project, and Taimur Martin, a young English teacher being held hostage in Beirut. And The Echo Maker follows, on the one hand, accident victim Mark Schluter and his sister Karin, and on the other the famous (Oliver Sachs type) brain specialist Gerald Weber whose life is shaken by his encounter with the siblings.

of course there is nothing particularly uncommon about the use of two plots. And even though Powers does it consistently enough for it to be a hallmark of his style, this should probably come as no surprise, given that structures of binary opposition are so 
deeply implicated in so many of his obsessions-from genetics, computers, and the human brain to music and materialist history. What is highly unusual, however, is that his dual plots are not necessarily ever unified into a formal whole on anything but the most metaphoric level-and even on that level, their integration is generally not elegant or even complete. One has the sense-at least this one reader has the sensethat two never go neatly into one in Powers: that there is always a remainder, a sense that the two do not fit tightly or resolve in complete harmony.

3 I will propose that a name for this remainder might be "life," a notion to which I will return later. But first, let us consider a few examples of this non-integration. In Gain, the expectation or assumption, conditioned by such popular corporate conspiracy thrillers as Erin Brockovich and Michael Clayton, is that the two plots are causally related -that the history of the corporation provides an explanation for the cancer, and that in the end the plots will converge in the exposure of the corporation's venal villainy, perhaps leading to its demise. In Gain, however, while this possibility of a causal link is clearly presented, it is never conclusively affirmed; indeed, Laura herself suspects that finally, in such matters, "our total ignorance" is "incontestable" (320). Gain finally has a much larger project than the generic plot would encompass-the project of portraying capitalism not simply as antagonist to the individual, but rather as the encompassing system that produces everything, including the subject herself. As Laura thinks to herself in "a weird dream of peace[,] it makes no difference whether this business gave her cancer [though of course it also does make a difference]. They have given her everything else. Taken her life and molded it in every way imaginable, plus six degrees beyond imagining" (320).

As a result of this larger vision, Gain becomes the only novelistic critique of capitalism I can think of that effectively responds to Marx's own notion that, while capitalism is a mansion of horrors, "the dialectic," as Fredric Jameson puts it, "requires us to hold equally to a positive or 'progressive' evaluation of its emergence" (50). The "Gain" of the title is not only the non-fictional, very popular detergent and the capitalist hoarding of wealth made possible by such products, but also a nod to the technological gains that translate into the utter transformation of human existence, for both good and ill. We recall that these technological advances were also what Marx saw as the necessary contributions of the capitalist stage in preparing the way for a utopian postcapitalist future.

5 To the degree that the corporate and individual histories do converge at the end, part of the remainder, the leftover, is the human stories that make up the corporate history -the stories not only of creative individuals making scientific and technological breakthroughs, but also of all sorts of decisions, successes and failures, and choices positive as well as negative made by human actors within, and led along within, the larger system. These include the choices of scientists that entail all sorts of unforeseen consequences. What is left over is both a sense that despite the all-encompassing nature of the system human choices do count for something and, at the same time, a sense of why they do not count for more.

6 Finally, one more thing is left at the end-the sense that the two plots are not thematically related in precisely the dialectical structure we might imagine. The closing paragraphs synthesize the two stories on the level of fictional narrative, but whether this coming together offers synthesis in the sense of Aufhebung or sublation is radically unclear. Timothy, Laura's son, has become part of a research group that has 
solved the problem of protein folding, thereby offering "the key to a cell's life and death," and the possibility of a cure for cancer. The closing paragraph reads as follows:

It was then that Timothy Bodey mentioned a healthy bit of capital he had tucked away, untouched since childhood [this is the money given by Clare in settlement of any claims resulting from his mother's death]. The sum had been compounding forever, waiting for a chance to revenge its earning. The figure was now huge, a considerable bankroll. And softly, Tim suggested that it might be time for the little group of them to incorporate. (355)

The irony here is that what appears at first to be a new synthesis may, in the end, be only a repetition at a more complex technological level-one with new but not essentially different possibilities not only for technological advance and human comfort, but also for unintended consequences scientifically and exploitation economically. Whether this will constitute any sort of qualitative gain or qualitatively higher level is purely a matter of speculation.

8 The other novels I have mentioned offer similarly incomplete or ambiguous syntheses of their dual plots. The Echo Maker is the one that seems to conform most to conventions of narrative unity or connection between plots, which may well be why it is the one for which Powers finally won a major U.S. literary prize, the National Book Award. The two strands intertwine both narratively and thematically; in many ways what happens to Dr. Weber, and what he learns, are direct results of his encounter with Mark's case. What is odd about the strands, however, is the way that their raveling unravels, along with Weber himself. As the author has said, "the book is all about the long, inescapable descent into the messiness of existence":

This was my aim in Echo Maker: to put forward, at the same time, a glimpse of the solid, continuous, stable, perfect story we try to fashion about the world and about ourselves, while at the same time to lift the rug and glimpse the amorphous, improvised, messy, crack-strewn, gaping thing underneath all that narration. (Echo Maker Roundtable)

In this case, then, a greater superficial unity of story is used to expose the underlying disunity, and the papering over of the cracks, in all stories.

In contrast, Plowing the Dark is the case in which the two plots remain structurally most separate. They are joined only by a sort of mutual hallucination near the end, in which Adie Klarpol, floating above the floor of the virtual Haggia Sophia she and her colleagues have created, sees an unidentified man beneath her and falls to the floor, and Taimur Martin hallucinates that he is standing in the same building, looking up at an angel dropping to earth from above. Like the scene in Angels in America where Prior Walter and Harper Pitt, who have never met, encounter each other in their simultaneous hallucination, this meeting is possible only by magic. But in Powers' text, unlike Kushner's, this is pretty much the only magical element, and as a result it calls attention to itself as an authorial contrivance. Hence it also serves as a reminder that both plots, and perhaps more importantly their appearance in the same text, are authorial constructions.

11 The relation of the two plots in Plowing the Dark thus really only operates on the level of metaphor as, guided by the authorial cues, we juxtapose the plots thematically-one as a story of enhancement of, the other of reduction to, Plato's cave; one detailing a surfeit through art, the other a deprivation by terrorism, for the human sensorium. The metaphorical connections proliferate in ways too numerous to mention in any 
detail here, but they are founded on a rather radical disunity of narrative-a disunity, however, that bears none of the usual markers of experimentalism in fiction and hence does not cue the reader to expect its non-resolution.

Galatea 2.2 offers yet another case. Even at the end, it remains a bit hard to say how the story of Richard's relationship with C. fits with the story of the creation of Helen, the neural net. The structure here is further complicated by the fact that the time-frame in which Helen is being created also includes Richard's infatuation with and abortive attempt to romance A. Hence the dual plot becomes really two and a half plots (or perhaps 2.2?). Again there is a proliferation of connections; indeed narrator Richard tells us "Nothing in my story would ever go away [...]. C. spoke to me daily, through Helen's bewilderment. I saw how little I knew the woman I'd lived with for over a decade, in every turn that the stranger A. refused to take" (311-12). But again there is no sense of an ultimate formal or thematic unification or an epiphany of overall meaning. One wants to see the novel as a meditation on desire, its difficulties and frustrations, but one never feels one has a handle on how the parts fit together. Perhaps this incertitude and non-fulfillment are Powers' mimesis, on the level of structure, of desire's vicissitudes.

I suggested earlier that the remainder in Powers' texts might be called life ${ }^{2}$. Writing on Powers's work, Tom Leclair observes, "Born out of chance, affected by ecological constraints beyond its control, spreading and perpetuating itself by improbable variation, life is not designed." (Leclair 20). Rather, as the narrator of Three Farmers reminds us, "All lives are messy aggregates," and "Modern times are, by definition, a few billion times messier" (205). Our lives, our times, the world thus stand in opposition to art, which we tend to think of as a very high form of form. Even though art over the last century or so has tried more and more to include or contain chance and improbable variation and the "mess" of life, it nonetheless is always designed, if in no other way than its designation as art is always already a sign of design. Fictions are not life but, to paraphrase William Gass, "figures of life"; hence (Three Farmers again), "At the end, we all become edited copy" (163). "A book," Powers has said, " [...] may finally locate its greatest worth in its ability to refresh us to the irreducible complexity of the [...] world, a complexity whose scale and heft we might always have underestimated, without the shortfall of its ghostly imitations" ("Being and Seeming"). It is in order to come closer to life as LeClair describes it that Powers's figures or editions or books of life leave their loose ends unstitched.

As an epigraph to Galatea 2.2, Powers uses Emily Dickinson's poem 632, which begins with the claim that "The brain is wider than the sky" ${ }^{3}$ And indeed the book is, in large part, a celebration of the complexity of this amazing organ. Nonetheless, it seems to me that this appearance of the poem must be understood as ironic. In the end, neither the artificial brain (in its most advanced version known as implementation $\mathrm{H}$, or Helen), nor the human brain of A., Helen's competition on the Master's exam in the novel, can encompass all the multiple dimensions even of two lines from The Tempest. It is clear that A's answer, the "brilliant New Historicist reading" (326) is brilliant in its English grad school context, but equally clear that for the narrator its definitive dismissal of "any promise of transcendence" indicates that its brilliance operates within, indeed is made possible by, its parameters, which he seems to feel are clearly not as wide as the sky. 
Several other passages in this book may together indicate something of the complexity of the author's views on the relation of consciousness and narrative to what exceeds them. The first two express basically similar notions about the limits of literature. When the narrator remembers his break-up with his longtime partner, C., he tells of the moment when she was "struck" by "the senselessness of all stories-their total, arbitrary construction" (293). Later, he realizes that Helen "needed to know how little literature had, in fact to do with the real" (313). Since it is, in Powers, largely through stories that we try to encompass the world, such statements (while they are not his only or last words on the subject) must surely temper any easy faith in Dickinson's claim. Indeed, they may point to the conclusion that the sky is wider than the brain.

On the other hand, the narrator tells us, "All human effort, it seemed to me, aimed at a single end: to bring to life the storied curve we tell ourselves. Not so much to make the tale believable but only to touch it, stretch out in it" (312). These musings nicely complement an earlier passage of particular relevance for my overall argument, where this narrator, a novelist named Richard Powers, reflects on his first book, one that has not two but three distinct plot strands, all involving a photograph (as, of course, Powers' first novel, Three Farmers, does):

The key to that book, the one that preserves it for me, is that the triple braid -the magic driehoek of the photograph-fails to come together as expected. The lens does not have the last word, nor does the glance of the viewer, nor does the look of those boys, out over the shoulder of the photographer, back behind the lens. The dominant tense was now. The point of stories was what you did with them. (Galatea 2.2108 )

What "preserves" the book, what gives it continued life, is that its stories do not "come together as expected." And this non-convergence points to their point, which is their future life, and ours: what we do with them.

We make stories to try to contain the sky in the brain, but it will not be contained, which is precisely why we need the story as substitute, supplement, sustenance. But like supplements in general, stories repeat the absence of that which they seek to make present. Their non-resolution is a way of recognizing this repetition. It is a way at once of acknowledging nostalgia for the way we used to think art came together-for art as a lost center-and of opening to play. And play is ultimately the point of stories, ultimately what there is for us to do with them ${ }^{4}$.

In this light I will close with a few notes on what writing this essay, and indeed on what most of my reading of Powers, does to me. It makes me feel like The Echo Maker's Dr. Weber, a man who, having made a career (though mine certainly with nothing like the luster of Weber's) comes to question whether it is simply that he is losing his aptitude, or that he no longer has the determination and patience to put forth the effort to figure out what he might have gotten more quickly before. Or whether, in fact, it is that he is finally getting wise enough to realize that the assumption on which he had based his writing life-the assumption that histories, or texts, can be understood and the understanding conveyed to others-was the wrong one, however useful.

Certainly for Weber's counterparts among literary readers, aesthetic assumptions have changed as much as hermeneutic ones. The old New Critical assumption that texts should be well-formed, that everything should snap into place as the text snaps shut, has become the wrong one. While we can still love the elegance of form, we prefer that 
it stay open. As modern passes through post, and age passes through middle, Pandora may be American fiction's next top model. Even inveterate lovers of beauty (I am one) nonetheless come to ask first of our texts-as of our partners-that they be interesting.

But identification with Dr. Weber is not only a matter of age; indeed Powers himself has created images of men of failing powers (pun very much intended) from a rather early point in his career. Gold Bug's dying Ressler, Galatea's Powers, even to some degree the latter novel's Lentz are all, in different ways, at least cousins to Weber. They are their author's figures not so much of literal age, but of the aforementioned nostalgia for a past order, a vanished center. If, in the shadows of these characters, I approach the end of this writing with the sense that perhaps I have failed the novels, or perhaps have learned the inevitability of such failure, I am doing no more than yielding to the powers of the texts.

What, beyond my incapacity or the inevitability of failure, do these powers urge me to learn? First, one finds what one seeks. In the New Critical days of my youth, I'd have found unities and resolutions, however forced. Today, thinking there are none, to some extent I find myself fighting them off even as they try to whisper their possibilities to me. Metaphors proliferate. A few survive, and even thrive.

As to what we learn beyond that, I am going to take the easy way out: I am going to select a few lines from one of the novels as though they were the summation. The novel is the book that remains, to date, Powers' magnum opus, The Gold Bug Variations, in which, I would suggest, the author has cleverly disguised hermeneutics as science, as, for instance, in the following passage from Ressler: "Science is not about control. It is about cultivating a perpetual condition of wonder in the face of something [a remainder?] that forever grows one step richer and subtler than our latest theory about it. It is about reverence, not mastery" (411). But the purpose of this attitude of reverence is not to raise the great work above us. It is, as Jan later says about translating Shakespeare into Bantu, "not to extend the source [Shakespeare, the interpreted text] but to widen the target [the target language, the target of the text, the reader], to embrace more than was possible before" (491). To embrace what is left over?

If Gold Bug disguises hermeneutics as science, it equally cleverly masks writing as music: "What message," we are asked, "could anyone hear there, what terrible conversation except the same out-of-place, inexecutable instruction carried in the Linear B script [the genetic code] deep in the nucleus [of the cell]: feel this, grow, do more with what is scored here?" (572, emphasis in original). Or again, and at last, "The sense of all tune is to continue singing, in as many simultaneous melodies as possible" (630). The point is not to name and thereby pin down the tune, but to worry it, to keep tuning, to keep harmonizing, to keep splitting the lark (even if sometimes the best harmonies come from the attempt to sing the tune itself precisely). (And that is also why this paper ends with a parenthetical phrase). 


\section{BIBLIOGRAPHIE}

CHAMPION, Edward, “Echo Maker Roundtable \#5”, Edward Champion's Reluctant Habits, http:// www.edrants.com/echo-maker-roundtable-5/, October 20, 2006.

DERRIDA, Jacques. "Structure, Sign, and Play in the Discourse of the Human Sciences." Writing and Difference. Trans. Alan Bass. Chicago: U of Chicago P, 1978. 278-93.

HARRIS, Charles B. “'The Stereo View': Politics and the Role of the Reader in Gain." Review of Contemporary Fiction 18, no. 3 (1998): 97-109.

HEISE, Ursula K. “Toxins, Drugs, and Global Systems: Risk and Narrative in the Contemporary Novel." American Literature, 74 no. 4 (2002): 747-78.

JAMESON, Fredric. Postmodernism, or, The Cultural Logic of Late Capitalism. Durham: Duke University Press, 1991.

KIRN, Walter. “Commercial Fiction.” Review of Gain, by Richard Powers. New York June 15, 1998, 103.

LECLAIR, Tom. "The Prodigious Fiction of Richard Powers, William Vollmann, and David Foster." Critique: Studies in Contemporary Fiction. 38, no. 1 (1996): 12-37.

POWERS, Richard. "Being and Seeming: The Technology of Representation." Context 3 (2000). http://www.dalkeyarchive.com/article/show/120

-, Galatea 2.2. New York: Picador, Farrar, Straus, 1995.

-, Gain. New York: Farrar, Straus, 1998.

-, Plowing the Dark. New York: Farrar, Straus, 2000.

-, The Echo Maker. New York: Farrar, Straus, 2006.

-, The Gold Bug Variations. New York: Harper Perennial, 1992 [1991].

PENCE, Jeffrey. "The End of Technology: Memory in Richard Powers's Galatea 2.2." MLQ: Modern Language Quarterly 63 (2002): 343-63.

QUINN, Paul. "On the Tracks of the Rhino.” Review of Gain, by Richard Powers. Times Literary Supplement, March 17, 2000, 22.

SCOTT, A. O. "A Matter of Life and Death." Review of Gain, by Richard Powers. New York Review of Books, December 17, 1998, 38-42.

\section{NOTES}

1. Writing on Gain, Ursula K. Heise notes that "The juxtaposition of two story lines, which is also featured in Powers's other novels, has been widely commented upon by his reviewers." She points the reader to reviews by Walter Kirn, Paul Quinn, and A. O. Scott, as well as to Charles B. Harris's essay on Gain, which is probably the most frequently cited source on this element of Powers' narratives. Jeffrey Pence claims that the narrative structure of Galatea 2.2 is "bi-modal," though in a somewhat different way. While Pence seems to place more emphasis on what narrative can do in Powers, and I more on what it does not or cannot do (and why), his analysis is quite rich and we are in agreement on many points. 
2. Responding to an earlier draft of this essay, both of the anonymous referees complained, with complete justification, that I had not said what I meant by the term. One of them, however, speculated that I seem to mean "The experience of reversal, of open perspectives, of things not totalizeable." That's pretty much exactly what I do mean, and I thank the reader for this formulation.

3. I quote the poem from the version in Powers' novel, immediately following the copyright page. However, this version does not observe Dickinson's capitalization and punctuation.

4. The text to which this passage is indebted, as will no doubt be obvious to many readers, is Derrida's "Structure, Sign, and Play in the Discourse of the Human Sciences" ("La structure, le signe et le jeu dans le discours des sciences humaines"). See especially the essay's closing four paragraphs. For a critical reading compatible with my sense of Powers's combination of nostalgia and play, see Pence (360-61) on anamnesis and catamnesis in Galatea 2.2.

\section{RÉSUMÉS}

L'alternance de deux récits différents au sein d'une même narration constitue l'une des marques les plus saillantes de la technique narrative de Richard Powers. Cependant, les rapports qu'entretiennent ces deux récits varient sensiblement d'un roman à l'autre. Ils peuvent, d'un point de vue diégétique, reposer sur un même personnage, comme dans Galatea 2.2, ou sur la rencontre ponctuelle de divers protagonistes, comme dans The Echo Maker. Il arrive aussi qu'ils explorent un enchaînement présumé de cause à effet, comme dans Gain. Plus radicalement, dans Plowing the Dark, les deux récits paraissent tisser des liens essentiellement métaphoriques qui excluent plus ou moins toute idée de métonymie. Sur le plan de la signification, les deux récits semblent parfois former une unité lorsque combinaisons, parallèles et oppositions font se lever entre eux des rapports dialectiques. Ce travail met en évidence, dans plusieurs romans de Powers, les diverses permutations de cette structure à double récit et tente de cerner ce qui pourrait en constituer le « reste ", élément irréductible à toute unité thématique ou artistique. Si un tel reste existe, quel sens pourrait-il alors revêtir?

A prominent characteristic of Richard Powers' technique is that his novels generally proceed by the alternating narration of two different stories. The relations of one story to another vary quite widely, however. On the diegetic level, the two may have a common protagonist, as in Galatea 2.2; or they may concern the different but circumstantially intersecting lives of disparate figures, as in The Echo Maker; or they may explore a possible chain of cause and effect, as in Gain. Most radically, in Plowing the Dark, their relation seems to be more or less purely metaphoric, with little or no metonymic connection at all. On the level of meaning, the two stories may seem to form unities by operating in conjunction or parallel or in a more oppositional or dialectical relation. This paper outlines the different permutations of the two-story structure in a range of Powers' books. It also explores what, if anything, may be seen as the left-over, that which remains unassimilated to artistic or thematic unity, in various novels - and, if that remainder can be identified, what it might signify. 
INDEX

Keywords : Narrative structure, remainder, life, system, unity, disunity

Mots-clés : Structure narrative, reste, vie, système, unité, désunion

\section{AUTEUR}

THOMAS B. BYERS

University of Louisville 